\title{
RAPORTOWANIE KWESTII ZRÓWNOWAŻONEGO ROZWOJU ORAZ INTEGROWANIE DANYCH FINANSOWYCH I POZAFINANSOWYCH - PRAWNE UWARUNKOWANIA W POLSCE I NA ŚWIECIE
}

\section{WSTĘP}

Rozwój idei zrównoważonego rozwoju jest obecnie szeroko propagowany nie tylko w biznesie, lecz także w sektorze non profit. Wraz z wbudowaniem tej idei w strategię rozwoju organizacji sprawozdawczość z tego zakresu wydaje się naturalną konsekwencja, podobnie jak to ma miejsce przy raportowaniu danych finansowych. Podstawowym przedmiotem systemów rachunkowości i sprawozdawczości jest gospodarowanie kapitałem ekonomicznym. Systemy te odzwierciedlają $\mathrm{w}$ formie pieniężnej zjawiska i procesy gospodarcze oraz sytuację majątkową i wyniki działalności podmiotów gospodarczych ${ }^{1}$, tak aby w sposób prawidłowy, rzetelny i jasny przedstawić w księgach rachunkowych i sporządzanych na ich podstawie sprawozdaniach finansowych sytuację majątkowa i finansowa, wynik finansowy oraz rentowność jednostki ${ }^{2}$. Cel ten jest realizowany przez podmioty gospodarcze przez $-\mathrm{z}$ jednej strony - sporządzanie m.in. bilansów zysków i strat, z drugiej - poddawanie są kontroli w ramach audytów. Zagadnienie rodzajów wykorzystywanych narzędzi rachunkowości oraz metod ich stosowania w odniesieniu do gospodarowania kapitałem ekonomicznym jest w literaturze szeroko opracowane. Co więcej, stopień objęcia tego kapitału systemem rachunkowości i sprawozdawczości jest wystarczająco zaawansowany i ciagle doskonalony ${ }^{3}$. Negatywne skutki ekspansywnej działalności gospodarczej w postaci rabunkowego wykorzystywania zasobów naturalnych oraz nasilająca się presja otoczenia uruchomiły działania zmierzające do ujawniania w raportach informacji o środowisku przyrodniczym oraz o zachodzących w nim zmianach w celu uzyskania transparentności.

Potrzeba rozwijania sprawozdawczości na rzecz rozwoju zrównoważonego znajduje także swoje udokumentowanie w Agendzie 214, w której stwier-

${ }^{1}$ Konwencja terminologiczna reprezentowana w niniejszej publikacji w celu uwydatnienia jej walorów ekonomicznych wymaga posłużenia się pojęciem podmiotu gospodarczego, gdyż jest to najszersze pojęcie obejmujące swym zakresem zarówno przedsiębiorców, jak i organizacje non profit.

${ }^{2}$ B. Gierusz, Podręcznik samodzielnej nauki księgowania, Gdańsk 1998, s. 16-19.

${ }^{3}$ Por. B. Piontek, Rozwój zrównoważony $i$ trwaty $w$ miernikach oraz $w$ systemach sprawozdawczości, Bytom 2002, s. 88.

${ }^{4}$ Zatwierdzony podczas Szczytu Ziemi w Rio de Janeiro w 1992 r. dokument stanowiący zbiór zaleceń i działań na rzecz ochrony środowiska niezbędnych do podjęcia w XXI w. Agenda 21 była 
dza się, że nie należy ograniczać krajowych zasad rachunkowości jedynie do ewidencji zjawisk gospodarczych opłacanych w konwencjonalny sposób. Dokument ten zawiera postulat opracowania powszechnych zasad, które właczą - do obliczeń w stopniu zgodnym z racjonalną teorią i praktyką - wkłady wszystkich sektorów i szacunkową wartość działań społeczeństwa nieobjętych konwencjonalną księgowością. W dokumencie zaleca się opracowywanie zintegrowanych systemów rachunkowości środowiskowej (ekologicznej) i gospodarczej SEEA ${ }^{5}$ (ang. system of integrated environmental and economic accounting), które winny stanowić uzupełnienie tradycyjnych zasad rachunkowości. Jedyną formą realizacji tej rekomendacji jest publikowanie raportów zintegrowanych przez organizacje. Wiele z nich upowszechnia takie raporty z własnej inicjatywy, mając świadomość wymiernych korzyści tych działań. Niemniej jednak większość organizacji nie podejmuje tej aktywności, czego przyczyna może być niedostatecznie rozwinięte ustawodawstwo w tym zakresie. Kraje wysoko rozwinięte, jak Stany Zjednoczone czy Wielka Brytania, dostrzegaja potrzebę i korzyści płynące z kompleksowego uregulowania prawnego, które obliguje podmioty do ujawniania danych finansowych i pozafinansowych w ramach jednego raportu. Raportowanie to określa się mianem raportowania zintegrowanego.

Niski odsetek podmiotów publikujących raporty zrównoważonego rozwoju oraz raporty zintegrowane w Polsce skłania do refleksji. Niniejsze opracowanie stanowi przegląd regulacji prawnych obowiąujaccych w Polsce oraz w wybranych krajach Europy i na świecie, na tle których autorzy podjęli próbę sformułowania uwag de lege ferenda.

\section{ISTOTA RAPORTOWANIA ZRÓWNOWAŻONEGO I ZINTEGROWANEGO}

W ostatnich latach sytuacja polityczna i ekonomiczna podlega ciagłym zmianom. Globalny kryzys finansowy i gospodarczy wywołał ponowne zainteresowanie kwestiami regulacji. Ponadto kwestie środowiskowe, takie jak zmiany klimatu i degradacja ekosystemów, doprowadziły do coraz większej

\footnotetext{
najważniejszym z aktów przyjętych w Rio. Odnosiła się do wszystkich sfer środowiska i zakresów współpracy oraz zawierała wzajemne zobowiązania krajów bardziej rozwiniętych, ale równocześnie bardziej niszczących ekosystem - tzw. krajów Północy oraz krajów biedniejszych, słabo rozwiniętych - tzw. krajów Południa. Kraje Północy deklarowały działania na rzecz redukcji zużycia energii, zanieczyszczeń i odpadów. Południe natomiast obiecało większą ochronę lasów. Północ ponadto miała wspomóc kraje Południa w czystym ekologicznie rozwoju poprzez pomoc finansowa i udostępnienie nowoczesnych technologii. Zob. A. Bocian, Implementacja idei zrównoważonego rozwoju w procesie globalizacji, w: B. Poskrobka (red.), Zrównoważony rozwój gospodarki opartej na wiedzy, Wydawnictwo Wyższej Szkoły Ekonomicznej w Białymstoku, Białystok 2009, s. 82.

${ }^{5}$ System środowiskowo-gospodarczej rachunkowości (SEEA) - stanowi ramy opracowania prognoz opartych na kombinacji statystyk środowiskowych i gospodarczych. Analiza danych statystycznych dotyczących gospodarki i środowiska w tym samym czasie umożliwia wyodrębnienie różnych wzorców zrównoważonego rozwoju dla produkcji i konsumpcji. Por. Doskonalenie zasad rachunkowości gospodarczej i środowiskowej, http://cordis.europa.eu/result/rcn/91586 pl.html?isPermaLink=true [dostęp: 16.10.2015].
} 
liczby badań i inicjatyw majacych na celu udoskonalenie metod pomiaru i raportowania odpowiednich danych. Katalizatorem tych zmian jest także administracja publiczna, która poprzez rozmaite, „miękkie i twarde”, narzędzia wpływa na przedsiębiorców, aby w swojej działalności uwzględniali kwestie zrównoważonego rozwoju, a raportując dane pozafinansowe, polepszali procesy komunikacji wewnętrznej i zewnętrznej i zwiększali swoją konkurencyjność na rynku. Warto też wspomnieć o roli inwestorów, którzy w coraz większym stopniu przy dokonywaniu doboru inwestycji do portfela biora pod uwagę różne rodzaje ryzyka ESG 6 (ang. environmental, social responsibility, corporate governance), a firmy, jeżeli nie chcą zostać wyłączone z obszaru zainteresowania inwestorów, są zobowiązane przyjąć strategię $\mathrm{CSR}^{7}$ (ang. corporate social responsibility) i raportować swoje działania w tym zakresie ${ }^{8}$.

Według Global Reporting Initiative (GRI), największej organizacji zajmującej się zagadnieniem raportowania danych pozafinansowych, raportowanie kwestii zrównoważonego rozwoju polega na mierzeniu, ujawnianiu oraz ponoszeniu pełnej odpowiedzialności względem wewnętrznych i zewnętrznych interesariuszy za wyniki i wydajność w zakresie adresowania tych kwestii ${ }^{9}$. Termin ten jest często używany zamiennie wraz z pojęciami takimi, jak raportowanie danych pozafinansowych czy też raportowanie ESG. W ostatnim czasie popularność zyskuje również pojęcie raportowania zintegrowanego, odnoszącego się do publikowania w jednym raporcie danych finansowych i pozafinansowych.

${ }^{6}$ ESG - są to pozafinansowe obszary ryzyka brane pod uwagę podczas oceny emitentów papierów wartościowych przedsiębiorstw, państw i innych organizacji. Skrót ESG oznacza: E - środowisko (z ang. environmental), obszar ten dotyczy realizacji strategii i polityki środowiskowej, zarządzania środowiskiem, wywiązywania się z zasad odpowiedzialności i troski o środowisko, S - społeczna odpowiedzialność ( $\mathrm{z}$ ang. social responsibility), dotyczy relacji z udziałowcami na rynku, m.in. z dostawcami, klientami, partnerami. Ocenie podlegają warunki pracy, przestrzeganie praw pracowniczych i zasad BHP, polityka jakości w stosunku do procedur zarządzania i jakość produktu oraz polityka informacyjna przedsiębiorstwa i jego transparentność, G - ład korporacyjny (z ang. corporate governance), w tym obszarze pod uwagę brane sa takie aspekty, jak struktura zarządu przedsiębiorstwa, respektowanie praw udziałowców, respektowanie obowiązków informacyjnych względem wszystkich udziałowców, niezależność decyzyjna oraz umiejętności zarządcze. Głównym celem ESG jest dostarczenie inwestorom możliwości porównania na jednej płaszczyźnie alternatywnych kierunków inwestowania przez analizę tych 3 parametrów. Narzędziem, które pomaga zidentyfikować obszary ryzyka ESG (zarówno zagrożenia, jak i szanse) specyficzne dla danej organizacji, jest właściwie prowadzony dialog z interesariuszami. W Polsce dostawcą ratingów i ocen opartych na ESG jest Agencja Ratingu Społecznego (ARS).

${ }^{7}$ CSR - społeczna odpowiedzialność biznesu (z ang. corporate social responsibility) jest to styl zarządzania przedsiębiorstwem polegający na integrowaniu kwestii społecznych, środowiskowych, etycznych i dotyczących praw człowieka do działań biznesowych i strategii, we współpracy z interesariuszami (Komisja Europejska, 2011). Społeczna odpowiedzialność biznesu oznacza, że przedsiębiorstwo dobrowolnie uwzględnia interes społeczny i kwestie ochrony środowiska naturalnego w swojej działalności oraz w relacjach z grupami funkcjonujacymi w jej otoczeniu.

${ }^{8}$ Raportowanie ESG w przedsiębiorstwach państwowych $i$ spótkach z udziałem skarbu państwa, Analiza przygotowana dla rządowego Zespołu do spraw Społecznej Odpowiedzialności Przedsiębiorstw, Warszawa 2011, http://odpowiedzialnybiznes.pl/public/files/RaportowanieESG_ pp_ssp_2011.pdf [dostęp: 16.10.2015].

${ }_{9}$ Global Reporting Initative, Wytyczne do raportowania kwestii zrównoważonego rozwoju Wersja 3.09, 2006, http://www.globalreporting.org/rosourcelibrary/GRI-G3-Polish-Reporting-Guidelines.pdf [dostęp: 16.10.2015]. 
Raportowanie zintegrowane umożliwia dostarczenie rynkowi informacji pozafinansowych, dających pełniejszy obraz działalności przedsiębiorstwa, w tym lepszą ocenę różnych postaci ryzyka oraz szans dla danego biznesu. Według ekspertów z firmy doradczej Pricewaterhouse Coopers przekazywanie informacji na temat wskaźników pozafinansowych wpływa pozytywnie na konkurencyjność danej firmy na rynku oraz w danej społeczności. Według wytycznych Międzynarodowej Rady Raportowania Zintegrowanego (ang. International Integrated Reporting Council - IIRC), odpowiednio skonstruowane zintegrowane raporty powinny zawierać, obok danych finansowych, informacje o kapitale ludzkim, intelektualnym, społecznym, naturalnym - czyli wszystkie aspekty tworzące tzw. wartość dodaną danego przedsiębiorstwa ${ }^{10}$. Według Paula Druckmana, dyrektora generalnego IIRC, raportowanie zintegrowane nie zostało wprowadzone, aby zastapić raporty finansowe czy raporty zrównoważonego rozwoju. Jego główną rolą jest interpretacja kluczowych informacji z punktu widzenia procesu budowania wartości przedsiębiorstwa oraz zestawienie ich z takimi wskaźnikami, jak: strategia przedsiębiorstwa, ład korporacyjny czy wydajność przedsiębiorstwa ${ }^{11}$.

Eksperci z Pricewaterhouse Coopers słusznie wskazuja, że raportowanie zintegrowane jest kluczowym elementem dla przedsiębiorstw dążących do osiagnięcia długoterminowego sukcesu. Z przeprowadzonego przez tę firmę badania wynika, że przedstawiciele podmiotów gospodarczych zauważają tę prawidłowość i aktywnie uczestniczą w działaniach promujących ten transparentny sposób komunikacji z otoczeniem. Niemniej jednak wciąż niski odsetek publikowanych raportów zintegrowanych - wynikający prawdopodobnie z braku wiedzy na temat wszystkich istotnych zależności między wynikami finansowymi a niefinansowymi - pokazuje, że jest to dopiero początek drogi w kierunku świadomego tworzenia „wartości dodanej” przedsiębiorstw i jej efektywnego komunikowania ${ }^{12}$. Biorąc pod uwagę coraz większe zapotrzebowanie na przejrzyste i jasne informacje, wydaje się, że zintegrowany raport to doskonała możliwość zademonstrowania wewnętrznej integracji i spójności w firmie oraz szansa budowania trwałych więzi z zewnętrznymi interesariuszami ${ }^{13}$.

${ }_{10}$ Zob. http://www.pwc.pl/pl/biuro-prasowe/udostepnianie-informacji-pozafinansowych-w-raportach.jhtml [dostęp: 28.11.2013].

${ }_{11}$ R. Sroka, A. Grzymisławski, A. Kustra, Wytyczne w zakresie ujawniania danych pozafinansowych przedsiębiorstw, Ekspertyza przygotowana dla Ministerstwa Gospodarki przez Accreo Taxand i Akademię Górniczo-Hutnicza, Warszawa 2012, s. 19.

12 Ibidem. Badanie PwC zostało przeprowadzone wśród 50 największych globalnych firm (m.in. Deutsche Bank, Coca Cola Company, Natura, Unilever, Tata Steel) zaangażowanych w pilotażowy program prowadzony przez International Integrated Reporting Council (IIRC), którego celem jest pomoc w opracowaniu podstaw tzw. raportowania zintegrowanego. Z badania wynika, że 48\% firm informuje o zasobach oraz relacjach, na których opiera się ich model biznesowy; $83 \%$ globalnych firm analizuje przyszłe trendy rynkowe, jednak jedynie $40 \% \mathrm{z}$ nich wykorzystuje dyskusje w tym zakresie do podejmowania decyzji strategicznych. Z kolei 96\% ankietowanych raportuje swoje główne rodzaje ryzyka, jednak jedynie $23 \%$ łączy je z pozostałymi raportowanymi obszarami, odnosząc je m.in. do przyjętych wskaźników, na podstawie których oblicza się wyniki przedsiębiorstwa.

${ }^{13}$ R. Eccless, M. Krzus, One Report: Integrated Reporting for a Sustainable Strategy, John Wiley \& Sons, Canada 2010, s. 4. 
Mając na względzie powyższe, można pokusić się o sformułowanie definicji raportowania zintegrowanego i usystematyzować jego aspekty. Według autorów raportowanie zintegrowane to forma sprawozdawczości, której fundamentem jest holistyczne ujęcie organizacji w celu ujawnienia jej prawdziwej wartości.

\section{PRAWNE UWARUNKOWANIA RAPORTOWANIA ZRÓWNOWAŻONEGO I ZINTEGROWANEGO}

\section{Unijne regulacje prawne}

Dotychczasowe prawodawstwo UE, w szczególności Czwarta Dyrektywa w sprawie rocznych sprawozdań finansowych ${ }^{14}$, regulowało ujawnianie informacji niefinansowych w taki sposób, że firmy mogły dobrowolnie podjąć decyzję o upublicznieniu informacji środowiskowych, danych odnoszących się do ich aktywności społecznej lub innych aspektów działalności. Realizacja postanowień dyrektywy okazała się nieefektywna, ponieważ mniej niż $10 \%$ największych przedsiębiorstw UE ujawnia dane pozafinansowe regularnie ${ }^{15}$.

Komisja Europejska wzięła powyższe pod uwagę, tworząc strategię CSR na lata 2011-2014, w której poprawę ujawniania danych społecznych i środowiskowych uczyniła jednym z priorytetowych obszarów swojej działalności. Komisja wskazała ponadto, że pełna odpowiedzialność społeczna przedsiębiorstw jest możliwa jedynie poprzez wprowadzenie procesu integracji kwestii społecznych, środowiskowych, etycznych oraz z zakresu praw człowieka w ich działalności gospodarczej i strategii przy ścisłej współpracy z zainteresowanymi stronami.

W kwietniu 2013 r. Komisja przedstawiła propozycje zmian do istniejacych dyrektyw o rachunkowości ${ }^{16}$, rozszerzające obowiązek raportowania o dane niefinansowe dla wszystkich (nie tylko giełdowych) dużych europejskich przedsiębiorstw. Efektem prac Komisji jest dyrektywa 2013/34/UE ${ }^{17}$,

${ }^{14}$ Czwarta Dyrektywa Rady w sprawie rocznych sprawozdań finansowych niektórych rodzajów spółek, wydana na podstawie art. 54 ust 3 pkt g) Traktatu (78/660/EWG), Dz. Urz. L 222 z 14 sierpnia 1978 r., ze zm.

${ }_{15}$ R. Sroka, J. Kondraciuk, Komisja Europejska rozszerza obowiazki sprawozdawcze spółek, w: Transparentność w obszarze ESG, jako element przewagi konkurencyjnej spótki giełdowej, Warszawa 2013, s. 50.

${ }^{16}$ Istniejące już dyrektywy, o których mowa to: Siódma Dyrektywa Rady w sprawie skonsolidowanych sprawozdań finansowych (83/349/EWG), Dz. Urz. L 193 z 18 lipca 1983 r.; Czwarta Dyrektywa Rady w sprawie rocznych sprawozdań finansowych niektórych rodzajów spółek, wydana na podstawie art. 54 ust. 3 pkt g) Traktatu (78/660/EWG), Dz. Urz. L 222 z 14 sierpnia 1978 r., ze zm.

17 Dyrektywa Parlamentu Europejskiego i Rady z 26 czerwca 2013 r. w sprawie rocznych sprawozdań finansowych, skonsolidowanych sprawozdań finansowych i powiązanych sprawozdań niektórych rodzajów jednostek, zmieniająca dyrektywę Parlamentu Europejskiego i Rady 2006/43/WE oraz uchylajacca dyrektywy Rady 78/660/EWG i 83/349/EWG, Dz. Urz. L 182 z 26 czerwca 2013 r., s. 19. 
która uchyliła jednocześnie wcześniej obowiązujące dyrektywy 78/660/EWG i 83/349/EWG. Nowa dyrektywa dzieli przedsiębiorstwa na mikro, małe, średnie, duże i jednostki interesu publicznego. Ideą nowej regulacji jest zwiększenie wymogów sprawozdawczości wraz „z podwyższeniem” kategorii podmiotu - od mikroprzedsiębiorstw do dużych przedsiębiorstw i jednostek interesu publicznego. Dyrektywa ta przewiduje ujawnianie danych z zakresu takich obszarów, jak środowisko, kwestie społeczne i pracownicze, poszanowanie praw człowieka, przeciwdziałanie korupcji i łapówkarstwu, różnorodność kadry zarządzającej. Weryfikacja wdrażania nowych wytycznych będzie przebiegała zgodnie z zasada „zastosuj albo wyjaśnij, dlaczego nie stosujesz" (ang. comply or explain). W związku z czym przedsiębiorstwom pozostawiono pewien zakres swobody w podejmowaniu decyzji odnośnie do danych, które zostaną ujawnione. Zastrzeżono jednak konieczność złożenia wyjaśnienia w odniesieniu do danych nieujawnionych o przyczynach podjęcia takiej decyzji. Kraje członkowskie Unii Europejskiej maja czas na wprowadzenie w życie odpowiednich przepisów wdrażających postanowienia nowej dyrektywy do 20 lipca 2015 r. Moga jednak przewidzieć, że wdrażane przepisy po raz pierwszy będą miały zastosowanie do sprawozdań za lata obrotowe rozpoczynające się w 1 stycznia 2016 r. lub w trakcie roku kalendarzowego $2016^{18}$.

Wejście $\mathrm{w}$ życie proponowanych przez KE zmian legislacyjnych prawdopodobnie spowoduje wzrost dużych firm UE (z 2500 do ok. 18 000) regularnie raportujących dane środowiskowe i społeczne. Należy jednak podkreślić, że aktualny projekt opracowano z pominięciem najnowszych tendencji w sprawozdawczości, tj. raportowania zintegrowanego, dlatego istnieje duże prawdopodobieństwo, że niniejsza regulacja będzie podlegała zmianom w tym kierunku ${ }^{19}$.

\section{Regulacje prawne w wybranych krajach Europy i świata}

W ostatnich latach raportowanie kwestii związanych ze zrównoważonym rozwojem systematycznie rośnie ${ }^{20}$. W 2011 r. opublikowano prawie 6000 raportów, tj. dwa razy więcej niż w 2006 r. i trzy razy więcej niż w $2003^{21}$. Według badania przeprowadzonego przez KPMG z 2011 r. - 95\% z 250 największych firm na świecie ujawnia dane na temat swoich działań w zakresie odpowiedzialności społecznej i środowiskowej ${ }^{22}$. Najwięcej raportów zostało do tej pory opublikowanych w Japonii. Niewiele mniej powstało w Wielkiej Bry-

${ }^{18}$ R. Bujalski, Unia Europejska wprowadza nowa dyrektywe rachunkowa, http://www.lex.pl/ czytaj/-/artykul/ue-wprowadza-nowa-dyrektywe-rachunkowa [dostęp: 20.10.2014].

${ }^{19}$ R. Sroka, J. Kondraciuk, op. cit., s. 51.

${ }^{20}$ R. Sroka, Znaczenie raportowania spotecznego spótek giełdowych, w: Analiza ESG spótek $w$ Polsce. Budowanie wartości spótki poprzez raportowanie danych pozafinansowych ESG, Stowarzyszenie Emitentów Giełdowych, Accero Taxand, Warszawa 2013, s. 59.

${ }^{21}$ KPMG International, KPMG International Survey of Corporate Responsibility Reporting 2011, http://www.kpmg.com/PT/pt/IssuesAndInsights/Documents/corporate-responsibility2011.pdf [dostęp: 26.03.2014].

${ }^{22}$ CorporateRegister.com; 2012 Global Winners\&Reporting Trends; http://www.corporateregister.com/crra/help/CRRA-2012-Exec-Summary.pdf [dostęp: 29.11.2013]. 
tanii i Stanach Zjednoczonych. W polskiej bazie raportów społecznych znajdują się obecnie 163 dokumenty ${ }^{23}$.

Nowym trendem wyłaniajacym się w obszarze sprawozdawczości jest wspomniane już raportowanie zintegrowane. Wzrost rocznej ilości raportów zintegrowanych jest niewielki, ale stały. Kluczowe znaczenie dla poparcia raportowania zintegrowanego na szczeblu międzynarodowym i krajowym ma treść paragrafu 47 dokumentu końcowego Szczytu ONZ Rio +2024, który brzmi: „Uznajemy znaczenie raportowania kwestii zrównoważonego rozwoju i zachęcamy stosowne przedsiębiorstwa, zwłaszcza te notowane publicznie i duże firmy, do rozważenia integracji informacji na temat zrównoważonego rozwoju z ich cyklami raportowania. Zachęcamy branże, zainteresowane rządy, jak i odpowiednich interesariuszy przy wsparciu systemu ONZ do opracowania modeli dobrych praktyk i ułatwiania działań na rzecz integrowania raportowania zrównoważonego rozwoju, przy wzięciu pod uwagę doświadczeń z już istniejaccych ram, a także zwróceniu szczególnej uwagi na potrzeby krajów rozwijajaccych się, włączając w to budowanie ich potencjału"25.

Rządy Danii i Francji utworzyły specjalną grupę, nazywaną „Przyjaciółmi Paragrafu 47”, aby wyrazić poparcie dla integrowania kwestii finansowych i pozafinansowych w raportach rocznych. Każdy z tych krajów odgrywa już pewna rolę we wspieraniu raportowania kwestii zrównoważonego rozwoju, a ponadto Dania i Francja obok Wielkiej Brytanii, Szwecji i Hiszpanii wyróżniają się najsilniejszymi regulacjami w zakresie raportowania zintegrowanego. W Danii od początku 2009 r. obowiązuje zmieniona ustawa o sprawozdaniach finansowych, która, w myśl art. 99a, wymaga od 1100 największych duńskich przedsiębiorstw ujawniania w raportach rocznych informacji o formach realizowania polityki społecznej odpowiedzialności; jak przekładają się one na działalność spółki oraz jakie rezultaty przyniosła jej realizacja przedsięwzięć związanych z CSR i jakie ma oczekiwania co do działań w przyszłości ${ }^{26}$. W przypadku braku powyższych informacji w raporcie konieczne jest wyjaśnienie, dlaczego przedsiębiorstwo powstrzymuje się od takiego raportowania.

Francja była pierwszym krajem, który zobowiązał spółki publiczne do raportowania kwestii zrównoważonego rozwoju. W latach siedemdziesiątych wszystkie firmy zatrudniające powyżej 300 pracowników musiały publikować przegląd społeczny (fr. bilan social), zawierajacy ponad 100 wskaźników. $\mathrm{W}$ omawianym obszarze istotnym aktem prawnym była następnie ustawa o nowych regulacjach gospodarczych (fr. La loi relative aux nouvelles régulations économiques) z 2001 r., która nałożyła na firmy obowiązek raportowania wpływu środowiskowego i społecznego. Rozszerzono jej zakres ustawą Grenelle II,

${ }^{23}$ Raportyspoleczne.pl; Biblioteka Raportów, http://www.raportyspoleczne.pl/biblioteka_raportow/ [dostęp: 22.10.2014].

24 Szczyt ONZ, o którym mowa, odbył się w czerwcu 2012 r. w Rio de Janeiro.

${ }_{25}$ United Nations General Assembly, Resolution adopted by the General Assembly 66/288. The future we want, 11 September 2012, http://www.un.org/en/ga/search/view_doc.asp?symbol=\%20A/ RES/66/288 [dostęp: 15.10.2015].

${ }^{26}$ Danish Commerce and Companies Agency, Reporting on corporate social responsibility - an introduction for supervisory and executive boards, Danish Commerce and Companies Agency 2009, s. 9, http://samfundsansvar.dk/file/318919/reporting_corporate_social_responsibility_may_2009.pdf [dostęp: 26.03.2014]. 
która jest najsilniejszym jak do tej pory na świecie, ale równocześnie dość elastycznym aktem prawnym nakazującym raportowanie kwestii zrównoważonego rozwoju. Uchwalono ja w 2012 r.; wymaga ona od firm zawierania w rocznym sprawozdaniu z działalności informacji na temat szczegółowych wyników środowiskowych i społecznych odnoszących się zarówno do spółki głównej, jak i wszystkich spółek zależnych. Spółki giełdowe i największe firmy (powyżej 5000 pracowników i aktywa ogółem lub roczna sprzedaż netto 1 mld euro) były do tego zobowiązane już przy sporządzaniu raportów za rok 2012, a inne firmy od 2013 (powyżej 2000 pracowników i aktywa ogółem lub roczna sprzedaż netto 400 mln euro) oraz 2014 (powyżej 500 pracowników i aktywa ogółem lub roczna sprzedaż netto $100 \mathrm{mln}$ euro). Ustawa Grenelle II wymaga także zewnętrznego audytu procesu raportowania informacji pozafinansowych ${ }^{27}$.

Z kolei szwedzkie Ministerstwo Przedsiębiorstw, Energii i Komunikacji opublikowało w 2007 r. wytyczne zewnętrznego raportowania przez przedsiębiorstwa państwowe ${ }^{28}$. Zgodnie z wytycznymi, które weszły w życie z początkiem 2008 r., szwedzkie przedsiębiorstwa państwowe sa zobowiązane przedstawiać raporty zrównoważonego rozwoju zgodnie ze standardami GRI. Dla zapewnienia wysokiej jakości raportów wprowadzono również zapis o konieczności niezależnej weryfikacji ich treści oraz publikacji w tym samym czasie co sprawozdań rocznych.

Począwszy od 2012 r., także w Hiszpanii firmy sa zobowiązane do sporządzania raportów zrównoważonego rozwoju, zgodnie z ustawą 2/2011 z 4 marca 2011 r. o zrównoważonej gospodarce. Przepisy niniejszej ustawy wymagaja sporządzania raportu z danymi ESG przez firmy zatrudniajace ponad 1000 pracowników i powiadamiania o tym Rady Społecznej Odpowiedzialności Biznesu działajacej przy Ministerstwie Pracy i Imigracji.

Członkami wspomnianej grupy „Przyjaciół Paragrafu 47” sa także RPA oraz Brazylia. W RPA od 2010 r. firmy notowane na Giełdzie Papierów Wartościowych w Johannesburgu są zobowiązane do sporządzania raportu rocznego, który integruje wyniki finansowe i zrównoważonego rozwoju ${ }^{29}$. W Brazylii z kolei największa giełda BM \& FBOVESPA w São Paulo na początku 2012 r. wydała rekomendację dla spółek giełdowych na niej notowanych, aby w punkcie 7.8 formularza referencyjnego, do którego publikowania sa zobowiązane, określały, czy regularnie publikują raport zrównoważonego rozwoju, oraz jeśli to czynią - gdzie jest on dostępny, a jeśli nie raportują - dlaczego ${ }^{30}$.

${ }^{27}$ Institut RSE Management; The Grenelle II Act in France: a milestone towards integrated reporting; Paris 2012, s. 4, http://www.capitalinstitute.org/sites/capitalinstitute.org/files/docs/Institut\%20RSE\%20The\%20grenelle\%20II\%20Act\%20in\%20France\%20June\%202012.pdf [dostęp: 26.03.2014].

${ }^{28}$ Ministry of Enterprise, Energy and Communications; Guidelines for external reporting by state-owned companies, http://www.government.se/content/1/c6/09/41/25/56b7ebd4.pdf [dostęp: 26.03.2014].

${ }^{29}$ Integrated Reporting. Performance insight through Better Business Reporting, nr 1, KPMG 2011, s. 10, http://www.sustainabilitysa.org/Portals/0/Documents/road-to-integrated-reporting.pdf [dostęp: 26.03.2014].

${ }_{30}$ Odpowiedzialne-Inwestowanie.pl, Brazylijska giełda rekomenduje raportowanie ESG; http://www.odpowiedzialne-inwestowanie.pl/index.php/klasy-aktywow/przeglad/akcje-aktualnosci/463nowe-rekomendacje-gieldy-brazylijskiej-ws-raportowania-esg.html [dostęp: 20.11.2013]. 
Powyższe przykłady wskazują jednoznacznie, że wiele wysoko rozwiniętych krajów uznaje regulacje dotyczace raportowania zintegrowanego za istotne i czyni je elementem swojego systemu prawnego. Jednocześnie można dostrzec zastosowanie przez nie analogicznych rozwiązań w postaci zobligowania do sporządzania raportów zintegrowanych dużych organizacji, które mają znaczącą siłę oddziaływania na otoczenie oraz spółek giełdowych, a także wdrożenia zewnętrznej weryfikacji spójności ujawnianych danych w formie audytów. Podkreślić jednak należy, że regulacje prawne, mimo że bardzo skuteczne, nie są jedyną formą oddziaływania na organizacje. Czynnikiem motywującym do podnoszenia transparentności działalności przez raportowanie zintegrowane są także tzw. miękkie zachęty w postaci zaleceń i wytycznych ${ }^{31}$, które zastosował rząd holenderski. Uruchamiając „Benchmark Przejrzystości”, tj. krajowy system, który porównuje i ocenia pod względem przejrzystości raporty zrównoważonego rozwoju dobrowolnie uczestniczących w programie firm, umożliwił zainteresowanym podmiotom m.in. wgląd w treść raportów oraz porównywanie swoich wyników z wynikami krajowych i międzynarodowych podmiotów z danego sektora ${ }^{32}$.

\section{Regulacje prawne w Polsce}

W Polsce istnieje obecnie obowiązek publikowania danych pozafinansowych, będacy wynikiem wdrożenia unijnej dyrektywy modernizacji rachunkowości ${ }^{33}$, ale niestety nie jest on jeszcze egzekwowany. W art. 49 pkt 3 ustawy o rachunkowości ustawodawca wskazuje, że sprawozdanie z działalności jednostki powinno obejmować - o ile jest to istotne dla oceny sytuacji jednostki - wskaźniki finansowe i niefinansowe, łącznie z informacjami dotyczącymi zagadnień środowiska naturalnego i zatrudnienia, a także dodatkowe wyjaśnienia do kwot wykazanych w sprawozdaniu finansowym ${ }^{34}$. Z kolei rozporządzenie Ministra Finansów z 19 lutego 2009 r. wskazuje szczegółowy wykaz elementów, które takie sprawozdanie powinno zawierać, m.in. charakterystykę zewnętrznych i wewnętrznych czynników istotnych dla rozwoju przedsiębiorstwa emitenta, opis perspektyw rozwoju działalności emitenta ${ }^{35}$.

${ }^{31}$ Przykładami takich wytycznych moga być: „Program raportowania RSE.COOP” wydany przez hiszpańską konfederację przedsiębiorczości, czy „Wytyczne raportowania społecznego w sektorze finansowym” opublikowane przez Włoskie Stowarzyszenie Bankowości oraz Europejski Instytut Raportowania Społecznego.

32 Zob. http://seg.org.pl/pl/node/2130 [dostęp: 26.09.2014].

${ }^{33}$ Parlament Europejski i Rada, dyrektywa 2003/51/WE z 18 czerwca 2003 r., Dz. Urz. WE L 178 z 17 lipca 2003 r.

${ }^{34}$ Ustawa z 29 września 1994 r. o rachunkowości, Dz. U. 1994, Nr 121, poz. 591.

${ }^{35}$ Rozporządzenie Ministra Finansów z 19 lutego 2009 r. w sprawie informacji bieżących i okresowych przekazywanych przez emitentów papierów wartościowych oraz warunków uznawania za równoważne informacji wymaganych przepisami prawa państwa niebędącego państwem członkowskim, Dz. U. Nr 33, poz. 259. 
Na podstawie obowiązującej ustawy o rachunkowości wybrane jednostki ${ }^{36}$ sa zobligowane do sporządzania sprawozdań z działalności, które nie stanowią integralnej części sprawozdania finansowego. Analiza sprawozdania pozwala na właściwą ocenę efektów jej działalności w przeszłości oraz na ocenę jej przyszłego rozwoju, dlatego też należy w nim ujawnić nie tylko dane historyczne, ale również informacje prospektywne, które obejmują obszary dotyczące planów rozwoju firmy, przewidywaną sytuację finansowa, zagrożeń zarówno wewnętrznych, jak i zewnętrznych oraz czynniki ryzyka operacyjnego i o charakterze finansowym ${ }^{37}$. Szczegółowy zakres takiego sprawozdania ustawodawca określa w ust. 2 art. 49 niniejszej ustawy. Zauważyć należy, że owa lista nie zawiera nawet wzmianki o danych pozafinansowych dotyczacych środowiska naturalnego czy kapitału ludzkiego, co może powodować wrażenie, że ustawodawca uznaje takie dane za mało ważne, mające drugorzędne znaczenie. Wrażenie takie potęguje treść ust. 3 art. $49^{38}$, w którym obowiązek złożenia sprawozdania zawierającego wskaźniki pozafinansowe odnosi się do wskazanych w ust. 1 podmiotów tylko o tyle, „o ile jest to istotne dla oceny sytuacji jednostki”. Użyte przez ustawodawcę sformułowanie zdecydowanie nie motywuje jednostek do raportowania danych pozafinansowych, może natomiast skłaniać do wykazania braku potrzeby ich publikowania. Efekt ten może być spotęgowany faktem, że z nieujawnieniem ich w raporcie nie wiążą się żadne negatywne konsekwencje prawne.

Mimo obowiązujących regulacji „Analiza ESG spółek w Polsce” przeprowadzona przez Stowarzyszenie Emitentów Giełdowych, Crido Business Consulting oraz GES wskazuje, że zaledwie 5\% spółek notowanych na Giełdzie Papierów Wartościowych raportuje dane dotyczące środowiska naturalnego, a tylko 3\% ujawnia wartościowe dla odbiorców wskaźniki społeczne. Tak niski wynik skłania do refleksji i próby odpowiedzi na pytania, czy brak aktywności w tym zakresie nie jest skutkiem sposobu regulacji, w tym braku jej egzekwowania, czy może wynika z braku świadomości podmiotów o dalece pozytywnym wpływie raportowania zrównoważonego rozwoju na ich rozwój i postrzeganie przez interesariuszy ${ }^{39}$. W poszukiwaniu odpowiedzi na powyższe pytania należy spojrzeć na cały problem znacznie szerzej, wskazując grupy podmiotów, które odniosłyby korzyści z raportowania danych pozafi-

\footnotetext{
${ }^{36}$ Do kręgu tych jednostek należa: spółki kapitałowe (akcyjne i z ograniczoną odpowiedzialnościa), spółki komandytowo-akcyjne, towarzystwa ubezpieczeń wzajemnych, towarzystwa reasekuracji wzajemnej, spółdzielnie oraz przedsiębiorstwa państwowe.

${ }^{37}$ A. Wencel, Komentarz do art. 49 ustawy o rachunkowości, w: E. Walińska (red.), Ustawa o rachunkowości. Komentarz, wyd. 3, Lex, Warszawa 2013.

${ }^{38}$ Regulacja została wprowadzona w wyniku wdrożenia unijnej dyrektywy 2003/51/WE, tzw. dyrektywy modernizacji rachunkowości, która została wdrożona do polskiego prawodawstwa przez ustawę z 20 kwietnia 2004 r. o zmianie i uchyleniu niektórych ustaw w związku z uzyskaniem przez Rzeczpospolitą Polską członkostwa w Unii Europejskiej, Dz. U. 2004, Nr 96, poz. 959.

${ }^{39} \mathrm{~W}$ badaniu przeprowadzonym przez KPMG 250 największych firm na świecie za powody, dla których raportują kwestie zrównoważonego rozwoju, uznało: budowanie reputacji lub marki (67\%); kwestie etyczne (58\%); motywowanie pracowników (44\%); innowacje i uczenie się (44\%); zarządzenie ryzykiem i jego redukcja (35\%). Raportowanie CSR - Ankieta KPMG. Edycja 2013, https://www.kpmg.com/PL/pl/IssuesAndInsights/ArticlesPublication/Documents/mobile/Raportowanie-CSR.pdf [dostęp: 15.10.2015].
} 
nansowych, biorąc pod uwage istotne znaczenie raportowania tych danych w tworzeniu wartości przedsiębiorstwa. W chwili obecnej budowanie wartości przedsiębiorstwa jest postrzegane horyzontalnie i akcentuje pozyskiwanie korzyści nie tylko przez akcjonariuszy, jako dawców kapitałów, ale również pozostałe strony i grupy identyfikowane jako interesariusze zainteresowani funkcjonowaniem i budowaniem wartości przedsiębiorstwa. Interesariuszami przedsiębiorstwa moga być zarówno pracownicy, dostawcy, klienci, jak i gminy, samorządy lokalne, Skarb Państwa, banki, właściciele itp. Podczas procesu budowania wartości każda z wymienionych grup czerpie różne korzyści w postaci wynagrodzeń, podatków lokalnych, podatków centralnych, utrzymania rynków zbytu, zapewnienia przychodów, odsetek, dywidend itp. ${ }^{40}$, dlatego działania w celu zwiększenia odsetka podmiotów raportujacych dane pozafinansowe powinny być zintegrowane i prowadzone przez różne podmioty w zakresie ich kompetencji. Najbardziej pożądanymi działaniami wydaja się te, które byłyby prowadzone w obrębie obowiązujących regulacji, przekształcajac je tak, aby odsetek publikowanych raportów zrównoważonego rozwoju sukcesywnie rósł.

Warto w tym miejscu przytoczyć stanowisko Business Europe - organizacji reprezentującej na forum międzynarodowym firmy ze starego kontynentu, zgodnie z którym podejmowanie formalnych kroków prawnych powodujacych konieczność przechodzenia przez skomplikowane procedury legislacyjne pociaga za sobą ryzyko sprowadzenia raportowania do zwykłego odhaczania pól w formularzu. Z kolei zmiana istniejaccych regulacji polegająca jedynie na wprowadzeniu sankcji za brak raportowania mogłaby nie przynieść oczekiwanych rezultatów. Ponadto obowiązkowe ujawnianie danych pozafinansowych, szczególnie na poziomie UE, zdaniem tej organizacji mogłoby zniechęcić firmy do uwidaczniania informacji potencjalnie poufnych i wrażliwych w obawie przed konkurencja. Wydaje się zatem, że eksponowania i ochrony wymaga podejście tzw. business-driven ${ }^{41}$, którego zadaniem jest realizacja celów biznesowych przez rozwiązywanie problemów społecznych i środowiskowych ${ }^{42}$.

Kwestia braku wystarczajacych informacji na temat raportowania mogłaby zostać rozwiązana przez uzupełnienie obecnych regulacji projektem Krajowego standardu rachunkowości nr 8 „Sprawozdanie z działalności”. Ten 22-stronicowy dokument zawiera szeroki zakres wskazówek zarówno odnośnie do pożądanych cech, zawartości i struktury sprawozdania ESG, jak i dobrych praktyk w zakresie ich sporządzania. Podstawowym zadaniem Standardu jest promowanie sporządzania raportu oraz pomoc w jego przygotowaniu odpowiadającego oczekiwaniom jego użytkowników zgodnie z postanowieniami art. 49 i art. 55 ust. 2 ustawy o rachunkowości.

${ }^{40}$ R. Sroka, A. Grzymisławski, A. Kustra, op. cit., s. 9.

${ }^{41}$ Business-driven - jest to podejście odzwierciedlające potrzeby przedsiębiorstw. Podejście to ma na celu identyfikacje wszystkich kluczowych obszarów mających wpływ na przedsiębiorstwo, które należy wziąć pod uwagę przy planowaniu i rozwijaniu jego struktur i działalności. R. G. Ross, What does it mean to be business-driven? (Part 1), „Business Rules Journal” 3(5) 2002, http://www.BRCommunity.com/a2002/b103a.html [dostęp: 26.09.2014].

${ }^{42}$ R. Sroka, J. Kondraciuk, op. cit., s. 52. 
Powyższe rozważania wskazuja, że istniejące w Polsce rozwiązania prawne w niewystarczającym stopniu regulują kwestie sprawozdawczości pozafinansowej, tak ważnej nie tylko z punktu widzenia gospodarczego, ale także środowiskowego. Dlatego idąc za przykładem krajów UE, m.in. Danii czy Francji, warto rozważyć uchwalenie odrębnego aktu prawnego, który kompleksowo rozstrzygałby kwestie raportowania zintegrowanego. Niniejszy akt powinien narzucać obowiązek takiego raportowania dużym podmiotom gospodarczym od 250 pracowników i spółek giełdowych. Zdefiniowana powinna także zostać częstotliwość sporządzania raportów i ich zawartość, m.in. ujawnianie w raporcie informacji o strategii społecznej odpowiedzialności oraz o tym, jak przekłada się ona na działalność spółki oraz jakie rezultaty firma osiagnęła w swoich inicjatywach związanych z CSR i jakie ma oczekiwania co do działań w przyszłości. Ustawodawca powinien także zapewnić odpowiednie narzędzia prawne, które w sposób efektywny zwiększa ilość publikowanych raportów. Sankcjonowanie w karnoprawnym ujęciu mogłoby być demotywujące, dlatego powinno się rozważyć wprowadzenie czynników motywujących w postaci konkretnych przywilejów podatkowych. Wzrost zainteresowania inwestorów portfelem spółek odpowiedzialnych społecznie powoduje jednocześnie zwiększenie zainteresowania spółek kwestiami zrównoważonego rozwoju. Publikowanie raportów jest jednym z wymagań przynależności do portfela spółek ESG. Brak zewnętrznej kontroli zawartości publikowanych raportów może stanowić poważne ryzyko dla inwestorów. Dlatego też kolejnym elementem proponowanego aktu prawnego powinno być uregulowanie przewidujace poddanie się obligatoryjnej kontroli zewnętrznej, mającej na celu potwierdzenie zgodności publikowanych danych ze stanem rzeczywistym.

Nawet najmniejsza nowelizacja prawa z reguły pociaga za sobą koszty związane z jej wejściem w życie. W kontekście powszechnego postulatu ekonomicznej analizy regulacji prawnych konieczne jest wskazanie kosztów wprowadzenia proponowanych przez autorów zmian. Przedstawienie szczegółowych wyliczeń wymagałoby przeprowadzenia odrębnej analizy, która prawdopodobnie uzasadniałaby kolejną publikację. Dlatego też w tym miejscu wskazać można jedynie przypuszczalne konsekwencje i związane z nimi wydatki. Narzucenie obowiązu raportowania danych pozafinansowych dużym przedsiębiorstwom zapewne pociagnie za sobą konsekwencję wzrostu kosztów utrzymania komórek odpowiedzialnych za zbieranie, przetwarzanie i publikowanie raportów oraz komunikację z interesariuszami. Obligatoryjna, zewnętrzna kontrola raportów zrównoważonego rozwoju jest kolejnym kosztem dla przedsiębiorstw, który jednak w zestawieniu z korzyściami, w tym wzrostem wiarygodności przedsiębiorstwa w oczach inwestorów, nie wydaje się zbytnim obciążeniem finansowym. Motywowanie przedsiębiorstw do publikowania raportów zintegrowanych przez przyznawanie ulg podatkowych z pewnościa wygeneruje cała gamę kosztów po stronie Skarbu Państwa. Warto jednak wskazać, że to właśnie ulgi podatkowe obok dotacji sa jednym z najbardziej motywujacych czynników do działania. Mając natomiast na uwadze transparentność podmiotów gospodarczych, wzrost bezpieczeństwa na rynku kapitałowym, a w konsekwencji zwiększenie się ilości inwestorów - wydaje się, że regulacja tego typu miałaby rację bytu. 


\title{
IV. PODSUMOWANIE
}

Podsumowując dotychczasowe rozważania, należy podkreślić, że korzyści wynikające z raportowania zintegrowanego występują nie tylko po stronie organizacji, m.in. wzrost ich wartości na rynku kapitałowym czy poprawa wizerunku, lecz także po stronie Państwa i całej gospodarki, tj. wzrost transparentności działalności podmiotów gospodarczych czy też zwiększony napływ inwestorów. Dlatego też warto rozważyć przeprowadzenie reformy dotychczasowych regulacji z zakresu sprawozdawczości pozafinansowej, pomimo kosztów jej realizacji, które obciążą zarówno przedsiębiorstwo, jak i Państwo. Transformacja sprawozdawczości będąca skutkiem zmiany dotychczasowych regulacji pozwoli także na rozszerzenie kreowanego w tradycyjnych raportach finansowych statycznego wizerunku przedsiębiorstwa na rzecz zintegrowanego dynamicznego obrazu odzwierciedlającego permanentny dialog kierownictwa i pracowników przedsiębiorstwa z jego interesariuszami pozostającymi $\mathrm{w}$ otoczeniu gospodarczym.

\author{
dr Beata J. Kowalczyk \\ Uniwersytet Gdański \\ beata.kowalczyk@prawo.ug.edu.pl
}

mgr inż. Wojciech Kowalczyk

Szkoła Gtówna Handlowa w Warszawie

wk66236@doktorant.sgh.waw.pl

\author{
REPORTING ON SUSTAINABLE DEVELOPMENT AND THE INTEGRATION \\ OF FINANCIAL AND NON-FINANCIAL DATA: \\ LEGAL CONDITIONS IN POLAND AND WORLDWIDE
}

Summary

The idea of sustainable development is reflected in nearly all economic sectors which, along with the global advancement of new technologies, are developing at a very quick pace. Sustainable development is not an obstacle to this continued progress, but rather a call to maintain reason and moderation in order to reconcile areas of key importance to the humanity, that is economic growth and balanced distribution of profits. Owing to the widespread reach of this idea and to its presence in the development strategies of organisations in the business and non-profit sector, sanctioning reporting within this field, similarly to reporting financial data, seems like the natural consequence. Although reporting non-financial data and publication of integrated reports is becoming an increasingly common practice, undertaken by a growing number of organisations, the scale of this phenomenon invites the conclusion that it is still in its early stages. Numerous organisations publish such reports on their own initiative, as they are aware of the tangible advantages brought by such conduct. Still, many do not do it, probably due to lack of knowledge regarding all the important interrelations between financial and non-financial results, as well as due to insufficiently developed legal regulations pertaining to this area. Both the European Union and highly developed countries see the need and the advantages stemming from the complex legal regulation of this sphere, which is manifested in concrete legal acts. Although Poland too has regulations pertaining to this issue, the still low percentage of entities which publish reports on sustainable development and integrated reports, inspires reflections. Owing to this, the authors have reviewed legal regulations binding in Poland, in the European Union and in some selected countries in Europe and worldwide, based on which they have attempted to formulate a few de lege ferenda postulates. 
